\title{
Variation in the stearoyl-CoA desaturase gene (SCD) and its influence on milk fatty acid composition in late-lactation dairy cattle grazed on pasture
}

\author{
Yunhai $\mathrm{Li}^{1}$, Huitong $\mathrm{Zhou}^{1}$, Long Cheng ${ }^{2}$, Jenny Zhao ${ }^{1}$, and Jonathan Hickford ${ }^{1}$ \\ ${ }^{1}$ Department of Agricultural Sciences, Faculty of Agriculture and Life Sciences, \\ Lincoln University, Lincoln 7647, New Zealand \\ ${ }^{2}$ Faculty of Veterinary and Agricultural Sciences, Dookie College, \\ The University of Melbourne, Victoria 3647, Australia
}

Correspondence: Jonathan Hickford (jonathan.hickford@lincoln.ac.nz)

Received: 5 March 2020 - Revised: 22 July 2020 - Accepted: 3 September 2020 - Published: 3 November 2020

\begin{abstract}
Gene markers have become useful tools for improving animal genetics and breeding since they improve the accuracy of selection for superior breeding stock. In this study, the stearoyl-CoA desaturase ( $\Delta-9$ desaturase) gene $(S C D)$ was investigated in New Zealand pasture-grazed Holstein-Friesian $\times$ Jersey cows. Three nucleotide substitutions were identified in exon 5 of the gene (c.702A/G, c.762T/C and c.878C/T), and a single nucleotide substitution was identified in intron 5 (c.880+105A/G). The c.878C/T substitution would, if expressed, result in the amino acid substitution p.A293V. Four nucleotide substitutions (c.*1783A/G, c.*1883C/T,

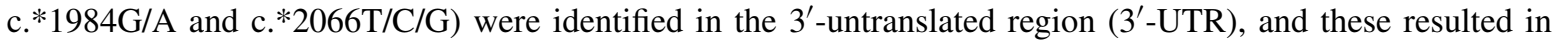
three nucleotide sequence variants (named $a, b$ and $c$ ). The sequence that would encode valine $(\mathrm{V})$ at position 293 of $S C D$ was linked to $3^{\prime}$-UTR variant $a$, and the sequence that would encode alanine (A) was linked to variants $b$ and $c$. The frequency of the genotypes was as follows: $V V$ (equivalent to $a a: 15.1 \%$ ), VA (equivalent to $a b+a c: 50.0 \%$ ) and $A A$ (equivalent to $b b+c c+b c: 34.9 \%$ ). The cows with the $V$ variant produced less C10:1, C12:1 and C14:1 fatty acid (FA) but more C10:0, C11:0, C14:0, C16:1 and C18:2 FA than the $A$ variant cows $(P<0.001)$. Effects of c. $* 1783 \mathrm{~A} / \mathrm{G}$ and c. $* 2066 \mathrm{~T} / \mathrm{C} / \mathrm{G}$ on milk fat composition were also found for the $A A$ cows. The presence of $c$ was associated with decreased levels of C16:1 $(P<0.001), \mathrm{C} 17: 1(P=0.001)$, C18:2 cis-9, trans-13 $(P=0.045), \mathrm{C} 18: 2$ cis-9, trans-12 $(P=0.018)$ FA and C16:1 FA index $(P<0.001)$. The presence of $b$ was associated with increased levels of C13:0 iso FAs $(P<0.001)$, monounsaturated FA (MUFA; $P=0.002)$ and $\mathrm{C} 12: 1(P<0.001)$.
\end{abstract}

\section{Introduction}

Stearoyl-CoA desaturase (SCD), also named $\Delta 9$-desaturase, can introduce a double bond at the $\Delta 9,10$ position in a large spectrum of fatty acids (FAs), and it is a rate-limiting enzyme in catalysing the synthesis of monounsaturated fatty acids (MUFAs) from saturated FAs (SFAs) (Nakamura et al., 2004; Paton et al., 2009). The main substrates for SCD are C16:0 and C18:0 FA, which can be converted into C16:1 cis9 and C18:1 cis-9 (Paton et al., 2009), but it can also catalyse the formation of cis-9, trans-11 conjugated linoleic acid (CLA) from C18:1 trans-11 (Ntambi et al., 2004).
The gene $(S C D)$ encoding for SCD is located on bovine chromosome 26, and it is expressed in a variety of tissues (Chung et al., 2000). In lactating ruminants, the expression of $S C D$ occurs at high levels (Bernard et al., 2005; Bionaz et al., 2008; McDonald et al., 1973), and it is considered to be important with respect to milk fat composition in these animals (Gautier et al., 2006). Ntambi et al. (2004) reported that dietary factors could regulate the expression of $S C D$, and hence the expression patterns of $S C D$ in cows that are grazing outdoor on pasture might therefore be different to cows that are fed indoors on supplements. This is supported by the observation of Elgersma (2015) that milk from grazing-based 
production systems has less SFA and more polyunsaturated FA (PUFA), which is considered beneficial for health.

Other than the effect of dietary factors, nucleotide sequence variation in $S C D$ is reported to be another factor that can change milk traits. For example, a nonsynonymous nucleotide substitution in $S C D$ exon 5 (c.878C/T), which causes the substitution of valine $(\mathrm{V})$ with alanine $(\mathrm{A})$ at position 293 of the protein (p.A293V), has been associated with some milk traits.

While Carvajal et al. (2016) and Valenti et al. (2019) did not find associations between p.A293V and the gross milk traits of milk yield, fat percentage and protein percentage, associations were reported between p.A293V and the levels of individual FAs (C10:0 to C18:0) in Italian Holstein, Piedmontese and Valdostana cattle (Mele et al., 2007; Moioli et al., 2007). A higher frequency of the alanine allele of p.A293V was found in the Holstein cows (0.57) (Mele et al., 2007), Valdostana cows (0.65) (Moioli et al., 2007) and Jersey cows (0.94) (Moioli et al., 2007), while Carvajal et al. (2016) reported frequencies of $0.65,0.81,0.89,0.56$ and 0.92, in Holstein, Jersey, Frisón Negro, Montbéliarde and Overo Colorado cattle respectively. In these breeds, the $S C D$ alanine allele was typically associated with a higher monounsaturated FA content.

In Japanese beef cattle, Taniguchi et al. (2004) identified more variants in the $3^{\prime}$-untranslated region ( $3^{\prime}$-UTR) of $S C D$, including c. $* 829 \mathrm{C} / \mathrm{T}$, c. $* 2066 \mathrm{~T} / \mathrm{C} / \mathrm{G}, \mathrm{c} . * 2273 \mathrm{G} / \mathrm{A}$, c. $* 2458 \mathrm{G} / \mathrm{A}$ and c. $* 3649 \mathrm{~A} / \mathrm{T}$ (these were labelled as 1905 , $3143,3351,3537$ and 4736 in their study), but the effect of these variations on intra-muscular fat composition was not significant, and their effect on milk FA is unknown. Hence, the objective of this study was to investigate the relationships between $S C D$ variation in two regions - the first spanning p.A293V and the second spanning the nucleotide variation identified by Taniguchi et al. (2004) - and milk traits in Kiwicross $^{\mathrm{TM}}$ cows during late lactation and in a wholly pasturebased outdoor dairy production system.

\section{Materials and methods}

\subsection{Cows studied and milk sample collection}

This research was approved by the Lincoln University Animal Ethics Committee (AEC Number 521) under the provisions of the Animal Welfare Act 1999 (NZ Government).

In total, 450 Holstein-Friesian $\times$ Jersey $(\mathrm{HF} \times \mathrm{J})$ crossbred (Kiwicross ${ }^{\mathrm{TM}}$ ) dairy cows from two herds (124 cows in herd 1 and 326 cows in herd 2) were studied. The cows were between 3 to 10 years of age, and they were grazed solely outdoors on pasture (a mixture of perennial ryegrass and white clover) on the Lincoln University Dairy Farm (LUDF; Canterbury, NZ). The cows calved over the period AugustSeptember, and they were then milked twice a day until the end of May in the following year.
The milk yield in litres per day was recorded using Trutest milk meters (Tru-test Ltd, Auckland, NZ). Milk samples for analysis were collected once a month from September to February, and these were analysed for fat percentage $(\%)$ and protein percentage $(\%)$ using Fourier-transform infrared spectroscopy (MilkoScan FT 120, Foss, Hillerød, Denmark). The milk samples for individual FA analysis were collected at one afternoon milking in mid-January (days in milk $(\mathrm{DIM})=148 \pm 19 \mathrm{~d})$ and frozen at $-20^{\circ} \mathrm{C}$. After freezing, the samples were freeze-dried and then individually ground to a fine powder for component analysis.

\subsection{Gas chromatography of the fatty acids in the milk sample}

Fatty acids in the milk samples were analysed by gas chromatography as FA methyl esters (FAME), as described in $\mathrm{Li}$ et al. (2019).

\subsection{PCR-SSCP analysis and genotyping}

A blood sample from each of the cows was collected onto FTA cards. These were air-dried and stored for analysis. For the genetic analysis, leukocyte DNA was purified from a $1.2 \mathrm{~mm}$ punch of the dried blood spot using the method described by Zhou et al. (2006).

Two pairs of PCR primers were designed based on the cattle reference sequence (NM_173959.4) to amplify two target regions of $S C D$. The first pair (forward: 5'-AATCAGGTAGGTCTCAGCG-3' and reverse: 5'-TTCTAATACTGTCCCTTAG-3') amplified a fragment of $436 \mathrm{bp}$ (Region 1) spanning part of intron 4, exon 5 and part of intron 5. The second pair (forward: 5'-GAACCACTGTTTCTCTTTAC- $3^{\prime}$ and reverse: $5^{\prime}$ CACTTTGGAACCTGCCTTTG-3') amplified a fragment of $397 \mathrm{bp}$ (Region 2) containing part of the $3^{\prime}$-UTR. The primers were synthesized by Integrated DNA Technologies (Coralville, IA, USA).

The PCR amplifications were performed as $15 \mu \mathrm{L}$ reactions containing the purified genomic DNA on a $1.2 \mathrm{~mm}$ punch of the purified FTA paper, $0.25 \mu \mathrm{M}$ of each designed primer, $150 \mu \mathrm{M}$ of each dNTP (Bioline, London, UK), $2.5 \mathrm{mM}$ of $\mathrm{Mg}^{2+}, 0.5 \mathrm{U}$ of Taq DNA polymerase (Qiagen, Hilden, Germany) and $1 \times$ the reaction buffer supplied with the DNA polymerase enzyme.

The amplifications were undertaken using S1000 thermal cyclers (Bio-Red, Hercules, CA, USA). The thermal profile included an initial denaturation for $2 \mathrm{~min}$ at $94^{\circ} \mathrm{C}$, which was followed by 35 cycles of $30 \mathrm{~s}$ at $94^{\circ} \mathrm{C}, 30 \mathrm{~s}$ at $50^{\circ} \mathrm{C}$ (for Region 1) or $56^{\circ} \mathrm{C}$ (for Region 2) and $30 \mathrm{~s}$ at $72^{\circ} \mathrm{C}$. A final extension was undertaken for $5 \mathrm{~min}$ at $72^{\circ} \mathrm{C}$.

Following the PCR amplifications, a $0.7 \mu \mathrm{L}$ aliquot of the products was mixed with $7 \mu \mathrm{L}$ of loading dye $(98 \%$ formamide, $10 \mathrm{mM}$ EDTA, $0.025 \%$ bromophenol blue, $0.025 \%$ xylene cyanol). After denaturation at $95^{\circ} \mathrm{C}$ for $5 \mathrm{~min}$ and 
rapid cooling on wet ice, the samples were loaded on $16 \mathrm{~cm} \times$ $18 \mathrm{~cm}, 12 \%$ acrylamide : bisacrylamide $(37.5: 1)$ (Bio-Rad) gels with $2 \%$ glycerol. Electrophoresis was performed using Protean II xi cells (Bio-Rad), at $390 \mathrm{~V}$ for $19 \mathrm{~h}$ at $12{ }^{\circ} \mathrm{C}$ in $0.5 \times$ TBE buffer. The method of Byun et al. (2009) was used to stain the gels.

\subsection{Sequencing of the $S C D$ variants and sequence analysis}

Homozygous PCR amplicons identified using PCR-SSCP were sequenced at the Lincoln University DNA Sequencing Facility. If homozygous samples were not found upon PCRSSCP analysis, individual variants were isolated from heterozygous cattle and sequenced using an approach described previously (Gong et al., 2011). Briefly, single bands of interest from the heterozygous cattle were recovered directly from the SSCP gels as a gel slice. This was macerated and the DNA was eluted into $50 \mu \mathrm{L}$ TE buffer by incubating at $70^{\circ} \mathrm{C}$ for $20 \mathrm{~min}$. The original primers and $1 \mu \mathrm{L}$ of the eluted solution (as a template) were used for a second round of PCR amplification to produce a simple SSCP gel pattern which could be directly compared to or found in, the pattern derived from the original heterozygous cow. When banding patterns could be matched and identified, then the second homozygous PCR amplicons were directly sequenced at the Lincoln University DNA Sequencing Facility.

The computer program DNAMAN (version 5.2.10, Lynnon BioSoft, Canada) was used for sequence alignment and comparisons. The BLAST algorithm was used to search the NCBI GenBank database (https://blast.ncbi.nlm.nih.gov, last access: 23 January 2020) for homologous sequences.

\subsection{Statistical analyses}

Hardy-Weinberg equilibrium (HWE) for the SCD genotypes was analysed using an online chi-square calculator (http://www.husdyr.kvl.dk/htm/kc/popgen/genetik/applets/ kitest.htm, last access: 2 April 2020). Other statistical analyses were carried out using IBM SPSS version 22 (IBM, NY, USA). Associations between variation in $S C D$ and variation in gross milk traits and milk FA traits were tested using general linear mixed-effects models (GLMMs).

Single-variant presence/absence models (fixed effects: DIM, age and herd) were used to ascertain which variants should be analysed in subsequent multi-variant models. The multi-variant models included any variant that had a variant - gross milk trait or variant - FA trait association in the single-variant presence/absence analysis with a $P$ value of less than 0.200 (and thus were potentially affecting the trait). The multi-variant models were again corrected for the fixed effects of (DIM, age and herd) and with other variants fitted as random effects.

A GLMM (fixed effect: genotype, DIM, age and herd) and multiple pair-wise comparisons with Bonferroni corrections (a)

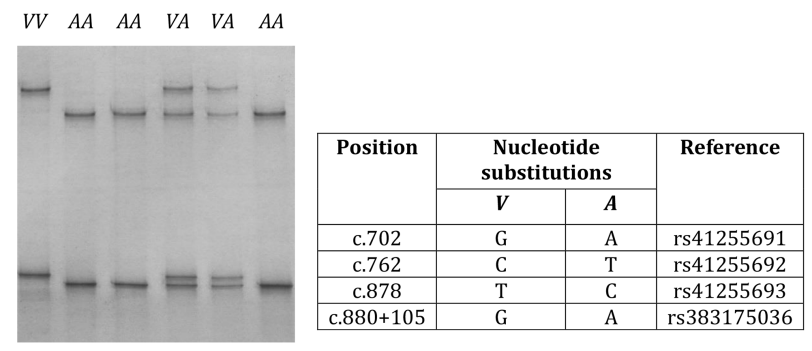

(b)

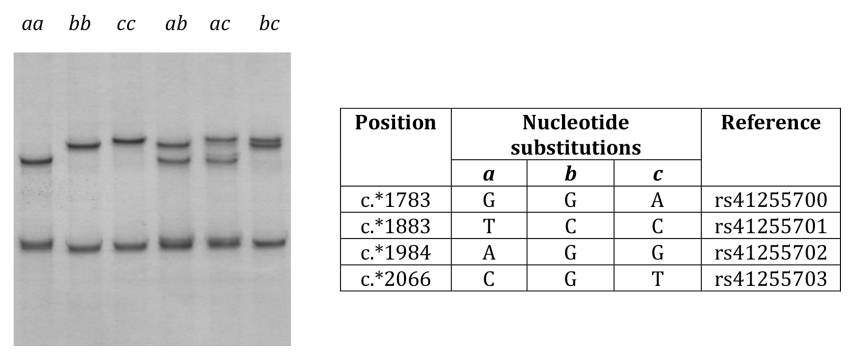

Figure 1. Variation in bovine $S C D$. Unique PCR-SSCP patterns representing different sequence variants of Region 1 (a) and Region 2 (b) are shown.

were used to ascertain the effect of the different genotypes with a frequency greater than $5 \%$ (thus insuring adequate sample size), on gross milk production traits (milk yield, fat percentage and protein percentage). Next, a GLMM (fixed effect: genotype, DIM, age and herd) and multiple pair-wise comparisons with Bonferroni corrections were used to ascertain the effect of genotypes on milk FA component levels.

The effect of cow sire could not be included in the GLMMs. Some semen straws (sire genetics) used in NZ dairy cattle artificial -insemination-based breeding approaches contain mixed-sire semen purchased from commercial semen producers. In these cases, individual sire identity is impossible to ascertain, but because the straws were mixed-semen straws and because different sires are used for different inseminations in different years, it is unlikely that sire was a strongly confounding effect. Cow age and herd might also be confounded with sire, but this cannot be confirmed.

\section{Results}

\subsection{Variation in $S C D$}

Eight nucleotide substitutions were found in the two regions of $S C D$ investigated (Fig. 1).

Three nucleotide substitutions (c.702A/G, c.762T/C and c.878G/A) in exon 5 and one nucleotide substitution (c.880+105A/G) in intron 5 (Region 1) and four nucleotide substitutions (c. $* 1783 \mathrm{~A} / \mathrm{G}$, c. $* 1883 \mathrm{C} / \mathrm{T}$, c.*1984G/A, and 
Table 1. Frequencies of $S C D 3^{\prime}$-untranslated region SNPs in the two herds of cows investigated.

\begin{tabular}{|c|c|c|c|c|}
\hline \multicolumn{2}{|c|}{ SNP } & \multirow[t]{2}{*}{ Variant } & \multicolumn{2}{|c|}{ Frequency (\%) } \\
\hline Position & Sequence & & Herd 1 & Herd 2 \\
\hline \multirow{2}{*}{ c. $* 1783$} & A & $c$ & 48.0 & 46.9 \\
\hline & G & $a, b$ & 52.0 & 53.1 \\
\hline \multirow[t]{2}{*}{ c. $* 1883$} & $\mathrm{C}$ & $b, c$ & 58.1 & 60.4 \\
\hline & $\mathrm{T}$ & $a$ & 41.9 & 39.6 \\
\hline \multirow[t]{2}{*}{ c. $* 1984$} & $\mathrm{G}$ & $b, c$ & 58.1 & 60.4 \\
\hline & A & $a$ & 41.9 & 39.6 \\
\hline \multirow[t]{3}{*}{ c. $* 2066$} & $\mathrm{~T}$ & $c$ & 48.0 & 46.9 \\
\hline & $\mathrm{C}$ & $a$ & 41.9 & 39.6 \\
\hline & G & $b$ & 10.1 & 13.5 \\
\hline
\end{tabular}

c. ${ }^{*} 2066 \mathrm{~T} / \mathrm{C} / \mathrm{G}$ ) in the $3^{\prime}$-UTR (Region 2 ) were found in the Kiwicross ${ }^{\mathrm{TM}}$ cows studied.

The variants $A$ and $V$ (from p.A293V), described in previous studies, were identified by these nucleotide variations (Fig. 1a), and three variants ( $a, b$ and $c$ ) could be identified when the $3^{\prime}$-UTR variations were analysed (Fig. 1b). A linkage was observed between c.702A/G, c.762T/C, c.878C/T, c. $880+105 \mathrm{~A} / \mathrm{G}, \mathrm{c} . * 1883 \mathrm{C} / \mathrm{T}$ and c. $* 1984 \mathrm{G} / \mathrm{A}$. The $V$ variant in Region 1 corresponded to 3'-UTR variant $a$ in Region 2 , and the $A$ variant in Region 1 corresponded to variants $b$ and $c$ in Region 2.

The overall frequency of the genotypes was $V V$ (equivalent to $a a: 15.1 \%$ ), $V A$ (equivalent to $a b+a c: 50.0 \%$ ) and $A A$ (equivalent to $b b+c c+b c: 34.9 \%$ ) across both herds, with the individual herds having frequencies of $A(58.13 \%)$ and $V(41.87 \%)$ for Herd 1 and $A(60.35 \%)$ and $V(39.66 \%)$ for Herd 2. Overall, the dominant variant was $A(59.9 \%)$ and the frequency of $V$ was $40.1 \%$. The $P$ value for the chi-square for deviation from HWE for p.A293V was 0.388, suggesting that across both herds the population was at equilibrium.

Six genotypes $a a, a b, a c, b b, b c$ and $c c$ were identified in the $3^{\prime}$-UTR region amplified, with overall frequencies of $15.1 \%, 10.7 \%, 39.3 \%, 1.8 \%, 10.7 \%$ and $22.4 \%$ respectively. The frequencies for the individual SNPs in both herds are illustrated in Table 1. The most common variant was $c$ (47.4\%), and the frequencies of $a$ and $b$ were $40.1 \%$ and $12.4 \%$. The $P$ value for the chi-square for deviation from HWE was 0.724 , suggesting that across both herds the population was at equilibrium.

\subsection{Milk traits, milk fat compositions and $S C D$ variation}

The average phenotypic measures for the gross milk traits of milk yield, milk fat percentage and milk protein percentage were $20.86 \pm 0.389 \mathrm{Ld}^{-1}, 5.07 \pm 0.044 \%$ and $4.22 \pm$ $0.024 \%$ respectively for Herd 1 . In Herd 2 they were $22.58 \pm$ $0.211 \mathrm{Ld}^{-1}, 5.06 \pm 0.031 \%$ and $4.11 \pm 0.017 \%$ respectively, but no associations were revealed between the $S C D$ variation and these gross milk traits. In contrast, Table 2 summarizes the associations revealed between the composition of milk fat and the $S C D$ variants defined by p.A293V.

Tables 3 and 4 summarize the associations revealed between the $S C D$ variants $a, b$ and $c$ and the composition of individual and grouped FAs respectively. The results are not presented if no association was found with the variants. Overall, the presence of variant $a$ was associated with lower C10:1 index, C12:1 index, and C14:1 index values but elevated C16:1 levels. Variant $b$ or $c$ appeared to have an opposite effect on the milk FAs when compared to variant $a$. There were higher C10:1 index, C12:1 index, C14:1 index and C18:1 index values when variant $b$ was present.

Table 5 summarizes the associations revealed between the composition of milk fat and the $S C D$ genotypes from the $3^{\prime}$-UTR variants. Results are only presented if an association was found. The frequency of the $b b$ genotype was low $(1.8 \%)$. Thus $b b$ cows were not included in the analyses. The effects of c. $* 2066 \mathrm{~T} / \mathrm{C} / \mathrm{G}$ and c. ${ }^{*} 1783 \mathrm{~A} / \mathrm{G}$ on milk fat composition were observed as the difference between $b c$ and $c c$ genotype cows, with there being less C16:1, C17:1, C18:2 cis-9, trans-13 and C18:2 cis-9, trans-12 in the milk from $c c$ cows.

\section{Discussion}

The enzyme SCD is a rate-limiting enzyme in the biosynthesis of many monounsaturated FAs (Ntambi et al., 2004), and sequence variation in $S C D$ has been revealed to affect milk fat composition. The $S C D$ gene is therefore considered to be a useful candidate gene for use in breeding programmes targeted at improving the nutritional value of milk. The most commonly described variation in $S C D$ is the variant c. $878 \mathrm{C} / \mathrm{T}$ located in exon 5. It underpins the substitution of the amino acid valine $(\mathrm{V})$ with alanine $(\mathrm{A})$ at amino acid position 293 in the SCD protein. The function of SCD is likely to be affected by p.A293V because it is located in the third histidine-rich region of the enzyme. This histidine-rich region has been revealed to be important for the catalytic activity of the enzyme (Shanklin et al., 1994).

There was linkage between c.878C/T and other variants. Taniguchi et al. (2004) identified linkage between three nucleotide substitutions c.702A/G, c.762T/C and c.878C/T in exon 5 of Japanese black cattle. Based on these three variants, they described the haplotype p.293V (GCT) and p.293A (ATC). This linkage was also found by Baeza et al. (2013) with the variant g.10153A $>\mathrm{G}$ (equivalent to c.702A/G here) being in complete linkage disequilibrium with $\mathrm{c} .878 \mathrm{C} / \mathrm{T}$ in the beef cattle they studied. In this study, three nucleotide variations in exon 5 (c.702A/G, c.762T/C and c.878C/T), one variant in intron $5(\mathrm{c} .880+105 \mathrm{~A} / \mathrm{G})$ and four variants in the $3^{\prime}-$ UTR (c.*1883C/T, c.*1984G/A, c.*1783A/G and c. $* 2066 \mathrm{~T} / \mathrm{C} / \mathrm{G})$ were revealed. There was linkage between 
Table 2. Association between milk fatty acid levels and p.A293V genotypes.

\begin{tabular}{|c|c|c|c|c|}
\hline \multirow[t]{2}{*}{ FAME } & \multicolumn{3}{|c|}{ Mean FAME level $\pm \mathrm{SE}^{1}\left(\mathrm{~g} 100 \mathrm{~g}^{-1}\right.$ milk FA $)$} & \multirow[t]{2}{*}{$P^{2}$} \\
\hline & $V V(n=68)$ & $V A(n=225)$ & $A A(n=149)$ & \\
\hline $\mathrm{C} 10: 0$ & $3.36 \pm 0.061^{\mathrm{a}}$ & $3.23 \pm 0.049^{b}$ & $3.16 \pm 0.054^{\mathrm{b}}$ & 0.002 \\
\hline C10:1 & $0.26 \pm 0.006^{\mathrm{c}}$ & $0.29 \pm 0.005^{b}$ & $0.32 \pm 0.005^{\mathrm{a}}$ & $<0.001$ \\
\hline C11:0 & $0.06 \pm 0.003^{\mathrm{a}}$ & $0.06 \pm 0.002^{b}$ & $0.06 \pm 0.003^{\mathrm{b}}$ & 0.011 \\
\hline $\mathrm{C} 13: 0$ iso & $0.07 \pm 0.001^{\mathrm{c}}$ & $0.08 \pm 0.002^{b}$ & $0.09 \pm 0.002^{\mathrm{a}}$ & $<0.001$ \\
\hline $\mathrm{C} 12: 1$ & $0.09 \pm 0.003^{\mathrm{c}}$ & $0.09 \pm 0.002^{b}$ & $0.10 \pm 0.003^{\mathrm{a}}$ & $<0.001$ \\
\hline $\mathrm{C} 13: 0$ & $0.13 \pm 0.004^{\mathrm{a}}$ & $0.12 \pm 0.003^{b}$ & $0.12 \pm 0.004^{\mathrm{b}}$ & 0.005 \\
\hline $\mathrm{C} 14: 0$ & $12.92 \pm 0.141^{\mathrm{a}}$ & $12.53 \pm 0.112^{b}$ & $12.36 \pm 0.124^{\mathrm{b}}$ & $<0.001$ \\
\hline C14:1 cis-9 & $0.80 \pm 0.027^{\mathrm{c}}$ & $0.98 \pm 0.021^{\mathrm{b}}$ & $1.17 \pm 0.024^{\mathrm{a}}$ & $<0.001$ \\
\hline C16:1 & $1.45 \pm 0.039^{\mathrm{a}}$ & $1.35 \pm 0.031^{\mathrm{b}}$ & $1.25 \pm 0.034^{\mathrm{c}}$ & $<0.001$ \\
\hline C17:0 iso & $0.54 \pm 0.011^{b}$ & $0.56 \pm 0.008^{\mathrm{a}}$ & $0.58 \pm 0.009^{\mathrm{a}}$ & 0.001 \\
\hline $\mathrm{C} 17: 1$ & $0.21 \pm 0.004^{\mathrm{a}}$ & $0.20 \pm 0.003^{\mathrm{ab}}$ & $0.20 \pm 0.004^{b}$ & 0.013 \\
\hline C18:2 cis -9, trans -13 & $0.30 \pm 0.006^{\mathrm{a}}$ & $0.29 \pm 0.005^{\mathrm{ab}}$ & $0.28 \pm 0.005^{\mathrm{b}}$ & 0.004 \\
\hline $\mathrm{C} 18: 2$ cis- 9, trans -12 & $0.08 \pm 0.004^{\mathrm{a}}$ & $0.08 \pm 0.003^{\mathrm{a}}$ & $0.07 \pm 0.003^{\mathrm{b}}$ & $<0.001$ \\
\hline MCFA & $21.53 \pm 0.273^{\mathrm{a}}$ & $20.88 \pm 0.218^{b}$ & $20.58 \pm 0.240^{\mathrm{b}}$ & 0.001 \\
\hline C10:1 index & $7.19 \pm 0.197^{\mathrm{c}}$ & $8.30 \pm 0.157^{b}$ & $9.37 \pm 0.173^{\mathrm{a}}$ & $<0.001$ \\
\hline C12:1 index & $2.09 \pm 0.051^{\mathrm{c}}$ & $2.31 \pm 0.041^{\mathrm{b}}$ & $2.53 \pm 0.045^{\mathrm{a}}$ & $<0.001$ \\
\hline C14:1 index & $5.82 \pm 0.194^{\mathrm{c}}$ & $7.27 \pm 0.155^{\mathrm{b}}$ & $8.64 \pm 0.170^{\mathrm{a}}$ & $<0.001$ \\
\hline C16:1 index & $3.72 \pm 0.086^{\mathrm{a}}$ & $3.44 \pm 0.069^{b}$ & $3.18 \pm 0.076^{\mathrm{c}}$ & $<0.001$ \\
\hline
\end{tabular}

c. $702 \mathrm{~A} / \mathrm{G}$, c. $762 \mathrm{~T} / \mathrm{C}$, c. $878 \mathrm{C} / \mathrm{T}$, c. $880+105 \mathrm{~A} / \mathrm{G}$, c. $* 1883 \mathrm{C} / \mathrm{T}$ and $\mathrm{c} * 1984 \mathrm{G} / \mathrm{A}$.

In an in vitro study, Enoch et al. (1976) revealed that the acyl-CoA derivatives with 12 to 19 carbon atoms were required as substrates for SCD enzyme activity. Schennink et al. (2008), Kgwatalala et al. (2009b) and this research (Table 1) all suggested that $S C D$ p.A293V has effects on individual FA and FA index levels, and especially in this study on the level of C10:0, C10:1, C12:1, C14:0, C14:1 and C16:1, as well as the $\mathrm{C} 10: 1$ index, $\mathrm{C} 12: 1$ index, $\mathrm{C} 14: 1$ and $\mathrm{C} 16: 1$ index levels. In addition, Enoch et al. (1976) found that the SCD enzyme has substrate specificity, with a preference for longer-chain FAs. However, the effect of p.A293V on C18 FA levels (such as the C18:1 trans-11, C18:1 cis-9, C18 index) was not confirmed here.

The effect of p.A293V on C18 FA levels could be influenced by different factors, including seasonal variation, the impact of other genes, variation between breeds and the stage of lactation. Duchemin et al. (2013) revealed that the p.293V allele was negatively associated with C18:1 trans-11 and that this negative effect was larger in summer than in winter. Schennink et al. (2008) investigated the joint effect of SCD and $D G A T 1$ variation and suggested that the genetic variation explained by $D G A T 1$ p. $232 \mathrm{~K}$ and by $S C D$ p.293A is additive with respect to their effect on C16, C18 and CLA levels. Moioli et al. (2007) revealed that p.A293V affected C10:1, C14:1, C16:1, C10 index and C14 index levels in Pied- montese $(n=81)$, Jersey $(n=75)$ and Valdostana $(n=730)$ cows, but the effect of p.293A on C18 levels was only observed when the variant frequency was high (i.e. when at a frequency of 0.94 in Jersey cattle and 0.65 in Valdostana cattle). With a lower frequency of occurrence of p.293A (i.e. 0.42 in Piedmontese cattle), the effect of $S C D$ variation on C18 levels was not significant. Mele et al. (2007) investigated the effect of p.293A and lactation stage on C18:1 cis9 FA levels. A negative effect was observed when the DIM increased $(P<0.01)$, and that p.293A occurrence (the frequency was 0.57 ) had a positive effect on the C18:1 cis-9 FA level $(P<0.05)$. Finally Carvajal et al. (2016) revealed associations between $S C D$ p.A293V genotypes and C6:0, C8:0, C10:0, C11:0, C14:0, C16:0, C18:0, C20:0, C16:1, C18:1 cis-9, linoleic acid, $\alpha$-linolenic acid and CLA cis-9 trans-11 levels.

In our study, a higher frequency of the p.293A allele $(59.9 \%)$ was observed in the Kiwicross ${ }^{\mathrm{TM}}$ cows. This is consistent with the findings of Schennink et al. (2008), Kgwatalala et al. (2009b) and Mele et al. (2007), who reported similar results, with frequencies of $73 \%$ in Dutch HF cows, $69 \%$ in Canadian HF cows and $57 \%$ in Italian HF cows, respectively.

The $3^{\prime}$-UTR can play a critical role in translation termination and post-transcriptional gene expression (Barrett et al., 2012). Baeza et al. (2013) reported that the $3^{\prime}$-UTR variant g. $15001 \mathrm{~A}>\mathrm{G}$ (equivalent to c.*1783A/G here) affected meat 
Table 3. Association between individual fatty acid levels and $S C D 3^{\prime}$-UTR variation.

\begin{tabular}{|c|c|c|c|c|c|c|c|}
\hline \multirow[t]{2}{*}{ FAME } & \multirow[t]{2}{*}{ Variant } & \multirow[t]{2}{*}{$\begin{array}{l}\text { Other variants in } \\
\text { the model }\end{array}$} & \multicolumn{4}{|c|}{$\begin{array}{l}\text { Mean FAME level } \pm \mathrm{SE}^{1} \\
\left(\mathrm{~g} 100 \mathrm{~g}^{-1} \text { milk FA }\right)\end{array}$} & \multirow[t]{2}{*}{$P^{2}$} \\
\hline & & & Absent & $n$ & Present & $n$ & \\
\hline \multirow[t]{6}{*}{ C10:0 } & $a$ & None & $3.16 \pm 0.053$ & 157 & $3.26 \pm 0.047$ & 293 & 0.004 \\
\hline & $b$ & None & $3.26 \pm 0.048$ & 346 & $3.17 \pm 0.055$ & 104 & 0.035 \\
\hline & $c$ & None & $3.28 \pm 0.053$ & 124 & $3.21 \pm 0.049$ & 326 & 0.076 \\
\hline & $a$ & $b, c$ & $3.16 \pm 0.068$ & 157 & $3.25 \pm 0.063$ & 293 & 0.030 \\
\hline & $b$ & $a, c$ & $3.26 \pm 0.069$ & 346 & $3.16 \pm 0.073$ & 104 & 0.029 \\
\hline & $c$ & $a, b$ & $3.26 \pm 0.079$ & 124 & $3.18 \pm 0.075$ & 326 & 0.067 \\
\hline \multirow[t]{6}{*}{ C10:1 } & $a$ & None & $0.32 \pm 0.006$ & 157 & $0.28 \pm 0.005$ & 293 & $<0.001$ \\
\hline & $b$ & None & $0.28 \pm 0.005$ & 346 & $0.31 \pm 0.006$ & 104 & $<0.001$ \\
\hline & $c$ & None & $0.28 \pm 0.006$ & 124 & $0.30 \pm 0.006$ & 326 & $<0.001$ \\
\hline & $a$ & $b, c$ & $0.32 \pm 0.018$ & 157 & $0.29 \pm 0.018$ & 293 & $<0.001$ \\
\hline & $b$ & $a, c$ & $0.29 \pm 0.019$ & 346 & $0.32 \pm 0.019$ & 104 & $<0.001$ \\
\hline & $c$ & $a, b$ & $0.29 \pm 0.022$ & 124 & $0.31 \pm 0.022$ & 326 & $<0.001$ \\
\hline \multirow[t]{6}{*}{$\mathrm{C} 13: 0$ iso } & $a$ & None & $0.09 \pm 0.002$ & 157 & $0.08 \pm 0.002$ & 293 & $<0.001$ \\
\hline & $b$ & None & $0.08 \pm 0.002$ & 346 & $0.09 \pm 0.002$ & 104 & $<0.001$ \\
\hline & $c$ & None & $0.08 \pm 0.002$ & 124 & $0.09 \pm 0.002$ & 326 & $<0.001$ \\
\hline & $a$ & $b, c$ & $0.09 \pm 0.006$ & 157 & $0.08 \pm 0.006$ & 293 & $<0.001$ \\
\hline & $b$ & $a, c$ & $0.08 \pm 0.006$ & 346 & $0.09 \pm 0.006$ & 104 & $<0.001$ \\
\hline & $c$ & $a, b$ & $0.08 \pm 0.007$ & 124 & $0.09 \pm 0.007$ & 326 & 0.002 \\
\hline \multirow[t]{6}{*}{ C12:1 } & $a$ & None & $0.10 \pm 0.003$ & 157 & $0.09 \pm 0.002$ & 293 & $<0.001$ \\
\hline & $b$ & None & $0.09 \pm 0.002$ & 346 & $0.10 \pm 0.003$ & 104 & $<0.001$ \\
\hline & $c$ & None & $0.09 \pm 0.003$ & 124 & $0.10 \pm 0.002$ & 326 & 0.074 \\
\hline & $a$ & $b, c$ & $0.10 \pm 0.005$ & 157 & $0.09 \pm 0.004$ & 293 & $<0.001$ \\
\hline & $b$ & $a, c$ & $0.09 \pm 0.005$ & 346 & $0.10 \pm 0.005$ & 104 & $<0.001$ \\
\hline & $c$ & $a, b$ & $0.10 \pm 0.006$ & 124 & $0.10 \pm 0.006$ & 326 & 0.126 \\
\hline \multirow[t]{6}{*}{ C14:0 } & $a$ & None & $12.36 \pm 0.124$ & 157 & $12.63 \pm 0.109$ & 293 & 0.002 \\
\hline & $b$ & None & $12.65 \pm 0.109$ & 346 & $12.30 \pm 0.127$ & 104 & $<0.001$ \\
\hline & $c$ & None & $12.65 \pm 0.123$ & 124 & $12.50 \pm 0.113$ & 326 & 0.109 \\
\hline & $a$ & $b, c$ & $12.39 \pm 0.235$ & 157 & $12.54 \pm 0.228$ & 293 & 0.101 \\
\hline & $b$ & $a, c$ & $12.68 \pm 0.169$ & 346 & $12.28 \pm 0.178$ & 104 & $<0.001$ \\
\hline & $c$ & $a, b$ & $12.61 \pm 0.244$ & 124 & $12.36 \pm 0.240$ & 326 & 0.015 \\
\hline \multirow[t]{6}{*}{ C14:1 } & $a$ & None & $1.17 \pm 0.026$ & 157 & $0.93 \pm 0.023$ & 293 & $<0.001$ \\
\hline & $b$ & None & $0.96 \pm 0.026$ & 346 & $1.11 \pm 0.030$ & 104 & $<0.001$ \\
\hline & $c$ & None & $0.91 \pm 0.029$ & 124 & $1.05 \pm 0.027$ & 326 & $<0.001$ \\
\hline & $a$ & $b, c$ & $1.14 \pm 0.092$ & 157 & $0.97 \pm 0.091$ & 293 & $<0.001$ \\
\hline & $b$ & $a, c$ & $0.98 \pm 0.106$ & 346 & $1.13 \pm 0.107$ & 104 & $<0.001$ \\
\hline & $c$ & $a, b$ & $1.00 \pm 0.116$ & 124 & $1.11 \pm 0.115$ & 326 & $<0.001$ \\
\hline \multirow[t]{6}{*}{$\mathrm{C} 16: 1$} & $a$ & None & $1.27 \pm 0.035$ & 157 & $1.37 \pm 0.031$ & 293 & $<0.001$ \\
\hline & $b$ & None & $1.33 \pm 0.032$ & 346 & $1.38 \pm 0.037$ & 104 & 0.057 \\
\hline & $c$ & None & $1.44 \pm 0.034$ & 124 & $1.29 \pm 0.031$ & 326 & $<0.001$ \\
\hline & $a$ & $b, c$ & $1.31 \pm 0.067$ & 157 & $1.38 \pm 0.065$ & 293 & 0.004 \\
\hline & $b$ & $a, c$ & $1.33 \pm 0.074$ & 346 & $1.37 \pm 0.075$ & 104 & 0.203 \\
\hline & $c$ & $a, b$ & $1.41 \pm 0.049$ & 124 & $1.29 \pm 0.046$ & 326 & $<0.001$ \\
\hline \multirow[t]{3}{*}{$\mathrm{C} 17: 0$ iso } & $a$ & None & $0.58 \pm 0.009$ & 157 & $0.56 \pm 0.008$ & 293 & 0.001 \\
\hline & $b$ & None & $0.56 \pm 0.008$ & 346 & $0.58 \pm 0.010$ & 104 & 0.017 \\
\hline & $c$ & None & $0.56 \pm 0.009$ & 124 & $0.57 \pm 0.009$ & 326 & 0.158 \\
\hline
\end{tabular}


Table 3. Continued.

\begin{tabular}{|c|c|c|c|c|c|c|c|}
\hline \multirow[t]{2}{*}{ FAME } & \multirow[t]{2}{*}{ Variant } & \multirow[t]{2}{*}{$\begin{array}{l}\text { Other variants in } \\
\text { the model }\end{array}$} & \multicolumn{4}{|c|}{$\begin{array}{l}\text { Mean FAME level } \pm \mathrm{SE}^{1} \\
\quad\left(\mathrm{~g} 100 \mathrm{~g}^{-1} \text { milk FA }\right)\end{array}$} & \multirow[t]{2}{*}{$P^{2}$} \\
\hline & & & Absent & $n$ & Present & $n$ & \\
\hline & $a$ & $b, c$ & $0.58 \pm 0.011$ & 157 & $0.56 \pm 0.010$ & 293 & 0.002 \\
\hline & $b$ & $a, c$ & $0.56 \pm 0.013$ & 346 & $0.58 \pm 0.013$ & 104 & 0.056 \\
\hline & $c$ & $a, b$ & $0.57 \pm 0.015$ & 124 & $0.57 \pm 0.014$ & 326 & 0.278 \\
\hline \multirow[t]{6}{*}{$\mathrm{C} 17: 1$} & $a$ & None & $0.20 \pm 0.004$ & 157 & $0.20 \pm 0.003$ & 293 & 0.023 \\
\hline & $b$ & None & $0.20 \pm 0.003$ & 346 & $0.21 \pm 0.004$ & 104 & 0.024 \\
\hline & $c$ & None & $0.21 \pm 0.004$ & 124 & $0.20 \pm 0.003$ & 326 & $<0.001$ \\
\hline & $a$ & $b, c$ & $0.20 \pm 0.006$ & 157 & $0.21 \pm 0.005$ & 293 & 0.473 \\
\hline & $b$ & $a, c$ & $0.20 \pm 0.005$ & 346 & $0.21 \pm 0.005$ & 104 & 0.188 \\
\hline & $c$ & $a, b$ & $0.21 \pm 0.004$ & 124 & $0.20 \pm 0.003$ & 326 & 0.001 \\
\hline \multirow[t]{5}{*}{ C18:1 cis-9 } & $a$ & None & $12.27 \pm 0.222$ & 157 & $13.05 \pm 0.196$ & 293 & 0.154 \\
\hline & $b$ & None & $12.97 \pm 0.196$ & 346 & $13.48 \pm 0.228$ & 104 & 0.003 \\
\hline & $c$ & None & $13.15 \pm 0.219$ & 124 & $13.08 \pm 0.201$ & 326 & 0.675 \\
\hline & $a$ & $\mathrm{~b}$ & $13.31 \pm 0.315$ & 157 & $13.17 \pm 0.301$ & 293 & 0.369 \\
\hline & $b$ & $\mathrm{a}$ & $12.97 \pm 0.196$ & 346 & $13.48 \pm 0.228$ & 104 & 0.003 \\
\hline \multirow[t]{5}{*}{ C18:2 trans $-9,12$} & $a$ & None & $0.41 \pm 0.006$ & 157 & $0.40 \pm 0.005$ & 293 & 0.042 \\
\hline & $b$ & None & $0.40 \pm 0.005$ & 346 & $0.40 \pm 0.006$ & 104 & 0.268 \\
\hline & $c$ & None & $0.39 \pm 0.006$ & 124 & $0.40 \pm 0.005$ & 326 & 0.024 \\
\hline & $a$ & $c$ & $0.40 \pm 0.007$ & 157 & $0.40 \pm 0.006$ & 293 & 0.117 \\
\hline & $c$ & $a$ & $0.39 \pm 0.006$ & 124 & $0.40 \pm 0.006$ & 326 & 0.046 \\
\hline \multirow[t]{5}{*}{ C18:2 cis-9, trans -13} & $a$ & None & $0.28 \pm 0.005$ & 157 & $0.29 \pm 0.005$ & 293 & 0.021 \\
\hline & $b$ & None & $0.29 \pm 0.005$ & 346 & $0.29 \pm 0.005$ & 104 & 0.804 \\
\hline & $c$ & None & $0.29 \pm 0.005$ & 124 & $0.28 \pm 0.005$ & 326 & 0.015 \\
\hline & $a$ & $c$ & $0.28 \pm 0.006$ & 157 & $0.29 \pm 0.005$ & 293 & 0.073 \\
\hline & $c$ & $a$ & $0.29 \pm 0.006$ & 124 & $0.28 \pm 0.005$ & 326 & 0.045 \\
\hline \multirow[t]{5}{*}{ C18:2 cis-9, trans -12} & $a$ & None & $0.07 \pm 0.003$ & 157 & $0.08 \pm 0.003$ & 293 & $<0.001$ \\
\hline & $b$ & None & $0.07 \pm 0.003$ & 346 & $0.07 \pm 0.003$ & 104 & 0.768 \\
\hline & $c$ & None & $0.08 \pm 0.003$ & 124 & $0.07 \pm 0.003$ & 326 & $<0.001$ \\
\hline & $a$ & $c$ & $0.07 \pm 0.004$ & 157 & $0.08 \pm 0.004$ & 293 & 0.001 \\
\hline & $c$ & $a$ & $0.08 \pm 0.005$ & 124 & $0.07 \pm 0.005$ & 326 & 0.018 \\
\hline \multirow[t]{5}{*}{ C19:0 } & $a$ & None & $0.14 \pm 0.004$ & 157 & $0.13 \pm 0.003$ & 293 & 0.036 \\
\hline & $b$ & None & $0.13 \pm 0.003$ & 346 & $0.13 \pm 0.004$ & 104 & 0.217 \\
\hline & $c$ & None & $0.13 \pm 0.004$ & 124 & $0.14 \pm 0.003$ & 326 & 0.026 \\
\hline & $a$ & $c$ & $0.14 \pm 0.004$ & 157 & $0.13 \pm 0.004$ & 293 & 0.099 \\
\hline & $c$ & $a$ & $0.13 \pm 0.004$ & 124 & $0.14 \pm 0.004$ & 326 & 0.055 \\
\hline \multirow[t]{5}{*}{ C20:0 } & $a$ & None & $0.12 \pm 0.002$ & 157 & $0.12 \pm 0.002$ & 293 & 0.011 \\
\hline & $b$ & None & $0.12 \pm 0.002$ & 346 & $0.12 \pm 0.003$ & 104 & 0.011 \\
\hline & $c$ & None & $0.12 \pm 0.002$ & 124 & $0.12 \pm 0.002$ & 326 & 0.380 \\
\hline & $a$ & $b$ & $0.12 \pm 0.003$ & 157 & $0.12 \pm 0.003$ & 293 & 0.031 \\
\hline & $b$ & $a$ & $0.12 \pm 0.003$ & 346 & $0.12 \pm 0.003$ & 104 & 0.029 \\
\hline \multirow[t]{3}{*}{ C22:5 cis-7, 10, 13, 16, 19} & $a$ & None & $0.12 \pm 0.004$ & 157 & $0.12 \pm 0.003$ & 293 & 0.041 \\
\hline & $b$ & None & $0.119 \pm 0.003$ & 346 & $0.12 \pm 0.004$ & 104 & 0.387 \\
\hline & $c$ & None & $0.121 \pm 0.004$ & 124 & $0.12 \pm 0.003$ & 326 & 0.687 \\
\hline
\end{tabular}

${ }^{1}$ Predicted means and standard error of those means derived from GLMM. "Cow age", "days in milk" and "herd" were fitted to the models as fixed effects. ${ }^{2} P<0.05$ in bold; $0.05<P<0.2$ in italics. 
Table 4. Association between grouped fatty acid levels and $S C D 3^{\prime}$-UTR variation.

\begin{tabular}{|c|c|c|c|c|c|c|c|}
\hline \multirow[t]{2}{*}{ FAME } & \multirow[t]{2}{*}{ Variant } & \multirow[t]{2}{*}{$\begin{array}{l}\text { Other variants in } \\
\text { the model }\end{array}$} & \multicolumn{4}{|c|}{$\begin{array}{l}\text { Mean FAME level } \pm \mathrm{SE}^{1} \\
\quad\left(\mathrm{~g} 100 \mathrm{~g}^{-1} \text { milk FA }\right)\end{array}$} & \multirow[t]{2}{*}{$P^{2}$} \\
\hline & & & Absent & $n$ & Present & $n$ & \\
\hline \multirow[t]{6}{*}{ MCFA } & $a$ & None & $20.57 \pm 0.239$ & 157 & $21.05 \pm 0.211$ & 293 & 0.005 \\
\hline & $b$ & None & $21.06 \pm 0.213$ & 346 & $20.54 \pm 0.247$ & 104 & 0.006 \\
\hline & $c$ & None & $21.11 \pm 0.237$ & 124 & $20.81 \pm 0.217$ & 326 & 0.093 \\
\hline & $a$ & $b, c$ & $20.62 \pm 0.378$ & 157 & $20.93 \pm 0.359$ & 293 & 0.090 \\
\hline & $b$ & $a, c$ & $21.11 \pm 0.314$ & 346 & $20.50 \pm 0.333$ & 104 & 0.003 \\
\hline & $c$ & $a, b$ & $21.04 \pm 0.400$ & 124 & $20.60 \pm 0.390$ & 326 & 0.026 \\
\hline \multirow[t]{5}{*}{ Total C18:1 } & $a$ & None & $16.72 \pm 0.257$ & 157 & $16.46 \pm 0.226$ & 293 & 0.148 \\
\hline & $b$ & None & $16.41 \pm 0.227$ & 346 & $16.86 \pm 0.264$ & 104 & $\mathbf{0 . 0 2 7}$ \\
\hline & $c$ & None & $16.55 \pm 0.253$ & 124 & $16.53 \pm 0.232$ & 326 & 0.920 \\
\hline & $a$ & $b$ & $16.75 \pm 0.309$ & 157 & $16.55 \pm 0.288$ & 293 & 0.266 \\
\hline & $b$ & $a$ & $16.41 \pm 0.227$ & 346 & $16.86 \pm 0.264$ & 104 & 0.027 \\
\hline \multirow[t]{5}{*}{ MUFA } & $a$ & None & $20.41 \pm 0.264$ & 157 & $19.98 \pm 0.233$ & 293 & 0.018 \\
\hline & $b$ & None & $19.90 \pm 0.233$ & 346 & $20.60 \pm 0.271$ & 104 & 0.001 \\
\hline & $c$ & None & $20.10 \pm 0.261$ & 124 & $20.09 \pm 0.240$ & 326 & 0.951 \\
\hline & $a$ & $b$ & $20.46 \pm 0.390$ & 157 & $20.13 \pm 0.374$ & 293 & 0.075 \\
\hline & $b$ & $a$ & $19.96 \pm 0.269$ & 346 & $20.61 \pm 0.299$ & 104 & 0.002 \\
\hline \multirow[t]{3}{*}{ Total branched FA } & $a$ & None & $1.633 \pm 0.022$ & 157 & $1.60 \pm 0.019$ & 293 & 0.018 \\
\hline & $b$ & None & $1.60 \pm 0.019$ & 346 & $1.62 \pm 0.022$ & 104 & 0.300 \\
\hline & $c$ & None & $1.59 \pm 0.021$ & 124 & $1.62 \pm 0.020$ & 326 & 0.212 \\
\hline \multirow[t]{5}{*}{ Total UFA } & $a$ & None & $24.45 \pm 0.314$ & 157 & $24.03 \pm 0.277$ & 293 & 0.052 \\
\hline & $b$ & None & $23.96 \pm 0.277$ & 346 & $24.64 \pm 0.323$ & 104 & 0.006 \\
\hline & $c$ & None & $24.15 \pm 0.310$ & 124 & $24.14 \pm 0.285$ & 326 & 0.955 \\
\hline & $a$ & $b$ & $24.50 \pm 0.416$ & 157 & $24.17 \pm 0.394$ & 293 & 0.137 \\
\hline & $b$ & $a$ & $24.00 \pm 0.301$ & 346 & $24.65 \pm 0.340$ & 104 & 0.010 \\
\hline \multirow[t]{5}{*}{ Total SFA } & $a$ & None & $68.46 \pm 0.342$ & 157 & $68.86 \pm 0.301$ & 293 & 0.093 \\
\hline & $b$ & None & $68.93 \pm 0.303$ & 346 & $68.30 \pm 0.352$ & 104 & 0.020 \\
\hline & $c$ & None & $68.72 \pm 0.337$ & 124 & $68.77 \pm 0.310$ & 326 & 0.850 \\
\hline & $a$ & $b$ & $68.43 \pm 0.418$ & 157 & $68.75 \pm 0.391$ & 293 & 0.185 \\
\hline & $b$ & $a$ & $68.90 \pm 0.316$ & 346 & $68.29 \pm 0.362$ & 104 & 0.026 \\
\hline \multirow[t]{5}{*}{ Total index } & $a$ & None & $26.32 \pm 0.342$ & 157 & $28.87 \pm 0.301$ & 293 & 0.058 \\
\hline & $b$ & None & $25.80 \pm 0.302$ & 346 & $26.51 \pm 0.352$ & 104 & 0.008 \\
\hline & $c$ & None & $26.01 \pm 0.338$ & 124 & $25.99 \pm 0.310$ & 326 & 0.925 \\
\hline & $a$ & $b$ & $26.37 \pm 0.445$ & 157 & $26.02 \pm 0.420$ & 293 & 0.145 \\
\hline & $b$ & $a$ & $25.84 \pm 0.326$ & 346 & $26.52 \pm 0.369$ & 104 & 0.012 \\
\hline \multirow[t]{5}{*}{ MUFA index } & $a$ & None & $23.09 \pm 0.315$ & 157 & $22.60 \pm 0.278$ & 293 & 0.025 \\
\hline & $b$ & None & $22.52 \pm 0.278$ & 346 & $23.29 \pm 0.324$ & 104 & 0.002 \\
\hline & $c$ & None & $22.74 \pm 0.312$ & 124 & $22.73 \pm 0.286$ & 326 & 0.965 \\
\hline & $a$ & $b$ & $23.14 \pm 0.444$ & 157 & $22.76 \pm 0.423$ & 293 & 0.086 \\
\hline & $b$ & $a$ & $22.59 \pm 0.317$ & 346 & $23.30 \pm 0.354$ & 104 & 0.005 \\
\hline \multirow[t]{6}{*}{ C10:1 index } & $a$ & None & $9.41 \pm 0.184$ & 157 & $8.01 \pm 0.162$ & 293 & $<0.001$ \\
\hline & $b$ & None & $8.12 \pm 0.177$ & 346 & $9.10 \pm 0.206$ & 104 & $<0.001$ \\
\hline & $c$ & None & $7.90 \pm 0.198$ & 124 & $8.66 \pm 0.182$ & 326 & $<0.001$ \\
\hline & $a$ & $b, c$ & $9.25 \pm 0.595$ & 157 & $8.24 \pm 0.589$ & 293 & $<0.001$ \\
\hline & $b$ & $a, c$ & $8.27 \pm 0.623$ & 346 & $9.22 \pm 0.626$ & 104 & $<0.001$ \\
\hline & $c$ & $a, b$ & $8.40 \pm 0.711$ & 124 & $9.07 \pm 0.706$ & 326 & $<0.001$ \\
\hline
\end{tabular}


Table 4. Continued.

\begin{tabular}{|c|c|c|c|c|c|c|c|}
\hline \multirow[t]{2}{*}{ FAME } & \multirow[t]{2}{*}{ Variant } & \multirow[t]{2}{*}{$\begin{array}{l}\text { Other variants in } \\
\text { the model }\end{array}$} & \multicolumn{4}{|c|}{$\begin{array}{l}\text { Mean FAME level } \pm \mathrm{SE}^{1} \\
\quad\left(\mathrm{~g} 100 \mathrm{~g}^{-1} \text { milk FA }\right)\end{array}$} & \multirow[t]{2}{*}{$P^{2}$} \\
\hline & & & Absent & $n$ & Present & $n$ & \\
\hline \multirow[t]{6}{*}{ C12:1 index } & $a$ & None & $2.54 \pm 0.048$ & 157 & $2.25 \pm 0.042$ & 293 & $<0.001$ \\
\hline & $b$ & None & $2.26 \pm 0.044$ & 346 & $2.51 \pm 0.051$ & 104 & $<0.001$ \\
\hline & $c$ & None & $2.25 \pm 0.050$ & 124 & $2.38 \pm 0.046$ & 326 & 0.001 \\
\hline & $a$ & $b, c$ & $2.53 \pm 0.134$ & 157 & $2.31 \pm 0.132$ & 293 & $<0.001$ \\
\hline & $b$ & $a, c$ & $2.30 \pm 0.127$ & 346 & $2.53 \pm 0.128$ & 104 & $<0.001$ \\
\hline & $c$ & $a, b$ & $2.36 \pm 0.164$ & 124 & $2.47 \pm 0.162$ & 326 & 0.004 \\
\hline \multirow[t]{6}{*}{ C14:1 index } & $a$ & None & $8.69 \pm 0.190$ & 157 & $6.89 \pm 0.168$ & 293 & $<0.001$ \\
\hline & $b$ & None & $7.05 \pm 0.191$ & 346 & $8.25 \pm 0.222$ & 104 & $<0.001$ \\
\hline & $c$ & None & $6.73 \pm 0.214$ & 124 & $7.75 \pm 0.197$ & 326 & $<0.001$ \\
\hline & $a$ & $b, c$ & $8.47 \pm 0.748$ & 157 & $7.17 \pm 0.742$ & 293 & $<0.001$ \\
\hline & $b$ & $a, c$ & $7.23 \pm 0.797$ & 346 & $8.41 \pm 0.800$ & 104 & $<0.001$ \\
\hline & $c$ & $a, b$ & $7.37 \pm 0.891$ & 124 & $8.26 \pm 0.887$ & 326 & $<0.001$ \\
\hline \multirow[t]{6}{*}{ C16:1 index } & $a$ & None & $3.23 \pm 0.078$ & 157 & $3.50 \pm 0.069$ & 293 & $<0.001$ \\
\hline & $b$ & None & $3.39 \pm 0.071$ & 346 & $3.52 \pm 0.083$ & 104 & 0.047 \\
\hline & $c$ & None & $3.67 \pm 0.076$ & 124 & $3.29 \pm 0.069$ & 326 & $<0.001$ \\
\hline & $a$ & $b, c$ & $3.34 \pm 0.172$ & 157 & $3.52 \pm 0.167$ & 293 & 0.002 \\
\hline & $b$ & $a, c$ & $3.40 \pm 0.187$ & 346 & $3.48 \pm 0.190$ & 104 & 0.251 \\
\hline & $c$ & $a, b$ & $3.60 \pm 0.112$ & 124 & $3.27 \pm 0.106$ & 326 & $<0.001$ \\
\hline \multirow[t]{3}{*}{ C18:1 index } & $a$ & None & $61.23 \pm 0.515$ & 157 & $61.02 \pm 0.454$ & 293 & 0.542 \\
\hline & $b$ & None & $60.75 \pm 0.453$ & 346 & $61.95 \pm 0.527$ & 104 & 0.003 \\
\hline & $c$ & None & $61.37 \pm 0.506$ & 124 & $60.91 \pm 0.464$ & 326 & 0.234 \\
\hline \multirow[t]{5}{*}{ CLA index } & $a$ & None & $27.23 \pm 0.420$ & 157 & $27.56 \pm 0.370$ & 293 & 0.259 \\
\hline & $b$ & None & $27.25 \pm 0.371$ & 346 & $28.05 \pm 0.432$ & 104 & 0.016 \\
\hline & $c$ & None & $27.95 \pm 0.411$ & 124 & $27.19 \pm 0.377$ & 326 & 0.015 \\
\hline & $b$ & $c$ & $27.34 \pm 0.446$ & 346 & $28.00 \pm 0.494$ & 104 & 0.053 \\
\hline & $c$ & $b$ & $27.97 \pm 0.477$ & 124 & $27.33 \pm 0.458$ & 326 & 0.049 \\
\hline
\end{tabular}

fat composition (C14:1 level, $P<0.05)$ in their Argentinian Brangus beef cattle. In the results reported here, after differentiating the p.293A variant to $b$ and $c$ (based on $3^{\prime}$-UTR typing), the different effects of the variants on long-chain FA levels were revealed. The decline in C16:1, C17:1, C18:2 cis9, trans-13 and C18:2 cis-9, trans-12 FA levels and C16:1 index level was associated with the presence of variant $c$. The presence of variant $b$ was associated with an increase in C18:1 cis-9 and total C18:1 FA levels, MUFA levels, C18:1 index level and MUFA index level. At the level of genotype (Table 5), there was a significant difference between $a a$ and cc cows in C16:1, C17:1, C18:2 cis-9, trans-13 and C18:2 cis-9, trans-12 FA levels. In addition, there was a significant difference between $a a$ and $b b$ cows for C20:0 levels and MUFA levels. This suggests the $3^{\prime}$-UTR (specifically the substitutions c.*1783A/G and c.*2066T/C/G) is better able to resolve the effect of $S C D$ on milk FA levels. In this respect, Kgwatalala et al. (2009b) regarded the effect of different lactation stages on milk MUFA was more important than
p.A293V, and this along with the results presented here suggests more research into $S C D$ variation and lactation stage is needed to gain clarity into what is driving variation in FA levels.

The influence of $3^{\prime}$-UTR variation was also described by Kgwatalala et al. (2009a) in 46 Holstein and 35 Jersey cows in Canada. In their study, three haplotypes H1, H2 and H3 (equivalent to the variants $c, b$ and $a$ here) were identified with the frequency $67.1 \%, 2.3 \%$ and $30.6 \%$ respectively. Significant differences were only found in two milk FA levels, with their $\mathrm{H} 1 \mathrm{H} 1$ cows producing more $\mathrm{C} 10: 1$ and $\mathrm{C} 12: 1$ than the $\mathrm{H} 3 \mathrm{H} 3$ cows (similar results were observed when comparing $c c$ and $a a$ cows here). Moreover, Kgwatalala et al. (2009a) reported that an internal ribosome entry site (IRES) could be found in the $c$ variant only. The presence of an IRES motif may ultimately affect SCD protein turnover or the quantity of the SCD enzyme produced, because it could enhance translation of the constituent mRNA. Kgwatalala et al. (2009a) suggested that the nucleotide vari- 
Table 5. Association between milk fatty acid levels and $3^{\prime}$-UTR genotypes ${ }^{1}$.

\begin{tabular}{|c|c|c|c|c|c|c|}
\hline \multirow[t]{2}{*}{ FAME } & \multicolumn{5}{|c|}{ 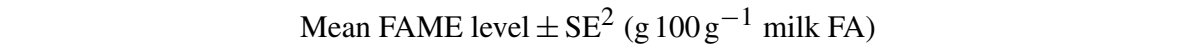 } & \multirow[t]{2}{*}{$P$} \\
\hline & $a a(n=68)$ & $a b(n=48)$ & $a c(n=177)$ & $b c(n=48)$ & $c c(n=101)$ & \\
\hline $\mathrm{C} 10: 0$ & $3.36 \pm 0.061^{\mathrm{a}}$ & $3.20 \pm 0.066^{\mathrm{ab}}$ & $3.24 \pm 0.051^{\mathrm{ab}}$ & $3.14 \pm 0.069^{\mathrm{b}}$ & $3.17 \pm 0.058^{\mathrm{b}}$ & 0.009 \\
\hline $\mathrm{C} 10: 1$ & $0.26 \pm 0.006^{\mathrm{c}}$ & $0.30 \pm 0.006^{\mathrm{b}}$ & $0.29 \pm 0.005^{\mathrm{b}}$ & $0.33 \pm 0.007^{\mathrm{a}}$ & $0.32 \pm 0.006^{\mathrm{a}}$ & $<0.001$ \\
\hline C11:0 & $0.06 \pm 0.003$ & $0.06 \pm 0.003$ & $0.06 \pm 0.002$ & $0.06 \pm 0.003$ & $0.06 \pm 0.003$ & 0.047 \\
\hline $\mathrm{C} 13: 0$ iso & $0.07 \pm 0.002^{\mathrm{d}}$ & $0.09 \pm 0.003^{\mathrm{bc}}$ & $0.08 \pm 0.002^{\mathrm{c}}$ & $0.10 \pm 0.003^{\mathrm{a}}$ & $0.09 \pm 0.002^{\mathrm{ab}}$ & $<0.001$ \\
\hline $\mathrm{C} 12: 1$ & $0.09 \pm 0.003^{\mathrm{c}}$ & $0.10 \pm 0.003^{\mathrm{ab}}$ & $0.09 \pm 0.002^{b c}$ & $0.10 \pm 0.003^{\mathrm{a}}$ & $0.10 \pm 0.003^{\mathrm{a}}$ & $<0.001$ \\
\hline C13:0 & $0.13 \pm 0.004^{\mathrm{a}}$ & $0.11 \pm 0.005^{\mathrm{b}}$ & $0.12 \pm 0.004^{\mathrm{ab}}$ & $0.12 \pm 0.005^{\mathrm{ab}}$ & $0.12 \pm 0.004^{\mathrm{b}}$ & 0.018 \\
\hline C14:0 & $12.93 \pm 0.140^{\mathrm{a}}$ & $12.35 \pm 0.151^{\mathrm{b}}$ & $12.59 \pm 0.118^{\mathrm{ab}}$ & $12.23 \pm 0.158^{b}$ & $12.45 \pm 0.134^{\mathrm{b}}$ & $<0.001$ \\
\hline C14:1 cis-9 & $0.80 \pm 0.027^{\mathrm{c}}$ & $1.01 \pm 0.029^{b}$ & $0.97 \pm 0.023^{\mathrm{b}}$ & $1.20 \pm 0.030^{\mathrm{a}}$ & $1.14 \pm 0.025^{\mathrm{a}}$ & $<0.001$ \\
\hline C16:1 & $1.44 \pm 0.039^{\mathrm{a}}$ & $1.41 \pm 0.042^{\mathrm{ab}}$ & $1.33 \pm 0.033^{\mathrm{b}}$ & $1.30 \pm 0.044^{b c}$ & $1.21 \pm 0.037^{\mathrm{c}}$ & $<0.001$ \\
\hline $\mathrm{C} 17: 0$ iso & $0.54 \pm 0.011^{\mathrm{b}}$ & $0.57 \pm 0.011^{\mathrm{ab}}$ & $0.56 \pm 0.009^{\mathrm{ab}}$ & $0.58 \pm 0.012^{\mathrm{a}}$ & $0.58 \pm 0.010^{\mathrm{a}}$ & 0.004 \\
\hline $\mathrm{C} 17: 1$ & $0.21 \pm 0.004^{\mathrm{a}}$ & $0.21 \pm 0.004^{\mathrm{ab}}$ & $0.20 \pm 0.003^{\mathrm{ab}}$ & $0.20 \pm 0.005^{\mathrm{ab}}$ & $0.20 \pm 0.004^{b}$ & 0.004 \\
\hline $\mathrm{C} 18: 2$ cis -9, trans -13 & $0.30 \pm 0.006^{\mathrm{a}}$ & $0.29 \pm 0.006^{\mathrm{ab}}$ & $0.29 \pm 0.005^{\mathrm{ab}}$ & $0.29 \pm 0.007^{\mathrm{ab}}$ & $0.28 \pm 0.006^{\mathrm{b}}$ & 0.011 \\
\hline C18:2 cis -9, trans -12 & $0.08 \pm 0.004^{\mathrm{a}}$ & $0.08 \pm 0.004^{\mathrm{a}}$ & $0.07 \pm 0.003^{\mathrm{a}}$ & $0.07 \pm 0.004^{\mathrm{ab}}$ & $0.07 \pm 0.004^{b}$ & $<0.001$ \\
\hline $\mathrm{C} 20: 0$ & $0.13 \pm 0.003^{\mathrm{a}}$ & $0.12 \pm 0.003^{\mathrm{ab}}$ & $0.12 \pm 0.002^{\mathrm{ab}}$ & $0.12 \pm 0.003^{\mathrm{b}}$ & $0.12 \pm 0.003^{\mathrm{ab}}$ & 0.044 \\
\hline MCFA & $21.55 \pm 0.273^{\mathrm{a}}$ & $20.66 \pm 0.295^{\mathrm{b}}$ & $20.96 \pm 0.230^{\mathrm{ab}}$ & $20.40 \pm 0.309^{b}$ & $20.70 \pm 0.260^{\mathrm{b}}$ & 0.002 \\
\hline MUFA & $19.87 \pm 0.300^{\mathrm{b}}$ & $20.24 \pm 0.323^{\mathrm{ab}}$ & $19.92 \pm 0.252^{\mathrm{b}}$ & $20.88 \pm 0.339^{\mathrm{a}}$ & $20.06 \pm 0.285^{\mathrm{ab}}$ & 0.020 \\
\hline MUFA index & $22.50 \pm 0.359^{\mathrm{ab}}$ & $22.87 \pm 0.387^{\mathrm{ab}}$ & $22.55 \pm 0.302^{\mathrm{b}}$ & $23.64 \pm 0.405^{\mathrm{a}}$ & $22.70 \pm 0.341^{\mathrm{ab}}$ & 0.036 \\
\hline C10:1 index & $7.17 \pm 0.196^{\mathrm{c}}$ & $8.56 \pm 0.211^{b}$ & $8.20 \pm 0.165^{\mathrm{b}}$ & $9.67 \pm 0.221^{\mathrm{a}}$ & $9.19 \pm 0.186^{\mathrm{a}}$ & $<0.001$ \\
\hline C12:1 index & $2.08 \pm 0.051^{\mathrm{d}}$ & $2.40 \pm 0.055^{\mathrm{bc}}$ & $2.280 \pm 0.043^{\mathrm{c}}$ & $2.61 \pm 0.057^{\mathrm{a}}$ & $2.47 \pm 0.048^{\mathrm{ab}}$ & $<0.001$ \\
\hline C14:1 index & $5.80 \pm 0.192^{\mathrm{c}}$ & $7.54 \pm 0.207^{b}$ & $7.160 \pm 0.161^{\mathrm{b}}$ & $8.99 \pm 0.216^{\mathrm{a}}$ & $8.43 \pm 0.182^{\mathrm{a}}$ & $<0.001$ \\
\hline C16:1 index & $3.71 \pm 0.085^{\mathrm{a}}$ & $3.57 \pm 0.092^{\mathrm{ab}}$ & $3.387 \pm 0.072^{\mathrm{b}}$ & $3.33 \pm 0.096^{\mathrm{bc}}$ & $3.09 \pm 0.081^{\mathrm{c}}$ & $<0.001$ \\
\hline CLA index & $27.79 \pm 0.470$ & $27.82 \pm 0.507$ & $27.376 \pm 0.395$ & $27.80 \pm 0.530$ & $26.63 \pm 0.447$ & 0.037 \\
\hline
\end{tabular}

${ }^{1}$ The genotypes with a frequency greater than $5 \%$ were analysed. Genotype $b b(n=8)$ occurred at a frequency of $1.78 \%$ and hence was not analysed. ${ }^{2}$ Predicted means and standard error of those means derived from GLMM. "Cow age", "days in milk" and "herd" were fitted to the models as fixed effects. Means within a row that do not share a superscript letter are separated by Bonferroni test at $P<0.05$.

ation in $3^{\prime}$-UTR region might lead to the absence of the IRES in the $a$ and $b$ variants.

With a low frequency of $b$ in their Holstein (0.054) and Jersey (0.000) cattle, Kgwatalala et al. (2009a) suggested that milk fat composition was not affected by variant $b$ significantly. Therefore, the variation in C10:1 and C12:1 FA levels in their study could be due to either the variation in the $3^{\prime}$ UTR (c.*1783A/G) or the variation in exon 5 (c.878C/T). If this was true, then the effect of $c$ on milk fat composition should be the opposite of the effects of $a, b$ or $a+b$. In the Kiwicross ${ }^{\mathrm{TM}}$ cows studied here the frequency of $b$ was 0.124 , and opposite effects were observed between variant $c$ and the other two variants for C16:1, C18:1 cis-9, C18:2 trans-9, 12, C18:2 cis-9, trans-12, C18:2 cis-9, trans-13, C19:0 FA levels and C16:1 index levels (Tables 3 and 4). At the genotype level (Table 5), the $c c$ cows produced more $\mathrm{C} 10: 1$ and $\mathrm{C} 12: 1$ FA than the $a a$ cows. This is similar to what was reported by Kgwatalala et al. (2009a). Moreover, the $a b$ cows produced less C10:1 and C14:1 cis-9 FA but more C18:2 cis-9, trans12 and $\mathrm{C} 16: 1 \mathrm{FA}$ than the $c c$ cows.

The effect of $S C D$ on gross milk traits (milk yield, fat and protein percentage) is still disputed. Macciotta et al. (2008) investigated 313 Italian Holstein cows and found that their
$V V$ cows (referring to p.A293V) had higher milk yields and protein yields than their $V A$ and $A A$ cows. The associations they found appear to be consistent across different stages of lactation. However, Mao et al. (2012) and Signorelli et al. (2009) reported a significant negative effect of the $V$ allele on milk yield in Chinese Holstein, Piedmontese and Valdostana breeds. In addition, Schennink et al. (2008) did not find any significant associations between p.A293V and milk traits in Dutch Holstein, a result that was consistent with our findings here in and Kiwicross ${ }^{\mathrm{TM}}$ cows.

Data availability. The original data are available upon request to the corresponding author.

Author contributions. YL, HZ, LC and JH conceived the research idea. YH performed the experiments, analysed the data and drafted the manuscript. HZ participated in statistic analysing and supplied the technical guidance. LC participated in the sampling. $\mathrm{JZ}$ performed the GC analysing. JH provided the experimental environment and participated in the manuscript writing. 
Competing interests. The authors declare that they have no conflict of interest.

Acknowledgements. We wish to thank Helen Hague from Lincoln University for sampling. We also thank the manager and staff of LUDF for their technical support.

Financial support. This research has been supported by the Ministry of Science and Innovation, New Zealand (grant no. DRCX 0802) and the Lincoln University Gene-Marker Laboratory.

Review statement. This paper was edited by Steffen Maak and reviewed by two anonymous referees.

\section{References}

Baeza, M. C., Corva, P. M., Soria, L. A., Pavan, E., Rincon, G., and Medrano, J. F.: Genetic variants in a lipid regulatory pathway as potential tools for improving the nutritional quality of grass-fed beef, Anim. Genet., 44, 121-129, https://doi.org/10.1111/j.13652052.2012.02386.x, 2013.

Barrett, L., Fletcher, S., and Wilton, S.: Regulation of eukaryotic gene expression by the untranslated gene regions and other non-coding elements, Cell. Mol. Life Sci., 69, 3613-3634, https://doi.org/10.1007/s00018-012-0990-9, 2012.

Bernard, L., Leroux, C., and Chilliard, Y.: Expression and nutritional regulation of lipogenic genes in the ruminant lactating mammary gland and adipose tissues of lactating goats, J. Dairy Res., 72, 250-255, https://doi.org/10.1007/978-0-38774087-4_2, 2005.

Bionaz, M. and Loor, J.: Gene networks driving bovine milk fat synthesis during the lactation cycle, BMC Genomics, 9, 366, https://doi.org/10.1186/1471-2164-9-366, 2008.

Byun, S. O., Fang, Q., Zhou, H., and Hickford, J. G. H.: An effective method for silver-staining DNA in large numbers of polyacrylamide gels, Anal. Biochem., 385, 174-175, https://doi.org/10.1016/j.ab.2008.10.024, 2009.

Carvajal, A. M., Huircan, P., Dezamour, J. M., Subiabre, I., Kerr, B., Morales, R., and Ungerfield, E. M.: Milk fatty acid profile is modulated by DGAT1 and SCD1 genotypes in dairy cattle on pasture and strategic supplementation, Genet. Mol. Res., 15, 15027057. https://doi.org/10.4238/gmr.15027057, 2016.

Chung, M., Ha, S., Jeong, S., Bok, J., Cho, K., Baik, M., and Choi, Y.: Cloning and characterization of bovine stearoyl CoA desaturasel cDNA from adipose tissues, Biosci. Biotech. Biochem., 64, 1526-1530, https://doi.org/10.1271/bbb.64.1526, 2000.

Duchemin, S., Bovenhuis, H., Stoop, W. M., Bouwman, A. C., Van Arendonk, J. A. M., and Visker, M. H. P. W.: Genetic correlation between composition of bovine milk fat in winter and summer, and DGAT1 and SCD1 by season interactions, J. Dairy Sci., 96, 592-604, https://doi.org/10.3168/jds.2012-5454, 2013.

Elgersma, A.: Grazing increases the unsaturated fatty acid concentration of milk from grass-fed cows: a review of the contributing factors, challenges and future perspectives, Eur. J. Lipid Sci.
Tech., 117, 1345-1369. https://doi.org/10.1002/ejlt.201400469, 2015.

Enoch, H. G., Catalá, A., and Strittmatter, P.: Mechanism of rat liver microsomal stearyl-CoA desaturase. Studies of the substrate specificity, enzyme-substrate interactions, and the function of lipid, J. Biol. Chem., 251, 5095-5103, 1976.

Gautier, M., Barcelona, R. R., Fritz, S., Grohs, C., Druet, T., Boichard, D., Eggen, A., and Meuwissen, T. H. E.: Fine mapping and physical characterization of two linked quantitative trait loci affecting milk fat yield in dairy cattle on BTA26, Genetics, 172, 425-436, https://doi.org/10.1534/genetics.105.046169, 2006.

Gong, H., Zhou, H., and Hickford J. G.: Diversity of the glycine/tyrosine-rich keratin-associated protein 6 gene (KAP6) family in sheep, Mol. Biol. Rep., 38, 31-35, https://doi.org/10.1007/s11033-010-0074-6, 2011.

Kgwatalala, P. M., Ibeagha-Awemu, E. M., Hayes, J. F., and Zhao, X.: Stearoyl-CoA desaturase 1 3'UTR SNPs and their influence on milk fatty acid composition of Canadian Holstein cows, J. Anim. Breed. Genet., 126, 394-403, https://doi.org/10.1111/j.1439-0388.2008.00796.x, 2009a.

Kgwatalala, P. M., Ibeagha-Awemu, E. M., Mustafa, A. F., and Zhao, X.: Stearoyl-CoA desaturase 1 genotype and stage of lactation influences milk fatty acid composition of Canadian Holstein cows, Anim. Genet., 40, 609-615, https://doi.org/10.1111/j.1365-2052.2009.01887.x, 2009b.

Li, Y., Zhou, H., Cheng, L., Edwards, G. R., and Hickford, J. G. H.: Effect of DGAT1 variant (K232A) on milk traits and milk fat composition in outdoor pasture-grazed dairy cattle, New Zeal. J. Agri. Res., https://doi.org/10.1080/00288233.2019.1589537, online first, 2019.

Macciotta, N. P. P., Mele, M., Conte, G., Serra, A., Cassandro, M., Dal Zotto, R., Cappio Borlino, A., Pagnacco, G., and Secchiari, P.: Association between a polymorphism at the stearoyl CoA desaturase locus and milk production traits in Italian Holsteins, J. Dairy Sci., 91, 3184-3189, https://doi.org/10.3168/jds.20070947, 2008.

Mao, Y. J., Chen, R. J., Chang, L. L., Chen, Y., Ji, D. J., Wu, X. X., Shi, X. K., Wu, H. T., Zhang, M. R., Yang, Z. P., König, S., and Yang, L. G.: Effects of SCD1- and DGAT1genes on production traits of Chinese Holstein cows located in the Delta Region of Yangtze River, Livest. Sci., 145, 280-286, https://doi.org/10.1016/j.livsci.2011.12.019, 2012.

McDonald, T. M. and Kinsella, J. E.: Stearyl-CoA desaturase of bovine mammary microsomes, Arch. Biochem. Biophys., 156, 223-231, https://doi.org/10.1016/0003-9861(73)90360-3, 1973.

Mele, M., Conte, G., Castiglioni, B., Chessa, S., Macciotta, N. P., Serra, A., Buccioni, A., Pagnacco, G., and Secchiari, P.: Stearoylcoenzyme $A$ desaturase gene polymorphism and milk fatty acid composition in Italian Holsteins, J. Dairy Sci., 90, 4458-4465, https://doi.org/10.3168/jds.2006-617, 2007.

Moioli, B., Contarini, G., Avalli, A., Catillo, G., Orru, L., De Matteis, G., Masoero, G., and Napolitano, F.: Short communication: effect of stearoyl-coenzyme A desaturase polymorphism on fatty acid composition of milk, J. Dairy Sci., 90, 3553-3558, https://doi.org/10.3168/jds.2006-855, 2007.

Nakamura, M. T. and Nara, T. Y.: Structure, function, and dietary regulation of delta6, delta5, and delta9 desaturases, Annu. Rev. Nutr., 24, 345-376, https://doi.org/10.1146/annurev.nutr.24.121803.063211, 2004. 
Ntambi, J. M. and Miyazaki, M.: Regulation of stearoyl-CoA desaturases and role in metabolism, Prog. Lipid Res., 43, 91-104, https://doi.org/10.1016/s0163-7827(03)00039-0, 2004.

Paton, C. M. and Ntambi, J. M.: Biochemical and physiological function of stearoyl-CoA desaturase, Am. J. Physiol.-Endoc. M., 297, E28-E37, https://doi.org/10.1152/ajpendo.90897.2008, 2009.

Schennink, A., Heck, J. M. L., Bovenhuis, H., Visker, M. H. P. W., Van Valenberg, H. J. F., and Van Arendonk, J. A. M.: Milk fatty acid unsaturation: genetic parameters and effects of stearoyl-CoA desaturase (SCD1) and acyl CoA: diacylglycerol acyltransferase 1 (DGAT1), J. Dairy Sci., 91, 2135-2143, https://doi.org/10.3168/jds.2007-0825, 2008.

Shanklin, J., Whittle, E., and Fox, B. G.: Eight histidine residues are catalytically essential in a membrane-associated iron enzyme, stearoyl-CoA desaturase, and are conserved in alkane hydroxylase and xylene monooxygenase, Biochemistry, 33, 1278712794, https://doi.org/10.1021/bi00209a009, 1994.

Signorelli, F., Orrù, L., Napolitano, F., De Matteis, G., Scatà, M. C., Catillo, G., Marchitelli, C., and Moioli, B.: Exploring polymorphisms and effects on milk traits of the DGAT1, SCD1 and GHR genes in four cattle breeds, Livest. Sci., 125, 74-79, https://doi.org/10.1016/j.livsci.2009.02.014, 2009.
Taniguchi, M., Utsugi, T., Oyama, K., Mannen, H., Kobayashi, M., Tanabe, Y., Ogino, A., and Tsuji, S.: Genotype of stearoyl-CoA desaturase is associated with fatty acid composition in Japanese Black cattle, Mamm. Genome, 15, 142-148, https://doi.org/10.1007/s00335-003-2286-8, 2004.

Valenti, B., Criscione, A., Moltisanti, V., Bordonaro, S., De Angelis, A., Marletta D., Di Paola, F., and Avondo M.: Genetic polymorphisms at candidate genes affecting fat content and fatty acid composition in Modicana cows: effects on milk production traits in different feeding systems, Animal, 13, 1-9, https://doi.org/10.1017/S1751731118002604, 2019.

Zhou, H., Hickford, J. G. H., and Fang, Q.: A two-step procedure for extracting genomic DNA from dried blood spots on filter paper for polymerase chain reaction amplification, Anal. Biochem., 354, 159-161, https://doi.org/10.1016/j.ab.2006.03.042, 2006. 